\title{
ASPECTS OF NON-STATE ARMED ACTORS AND FORMS OF VIOLENT GEOPOLITICS IN THE MIDDLE EAST
}

DOI: http://dx.doi.org/10.18509/GBP.2020.27

UDC: $657: 502.14]: 627$

\author{
Cosmin-Adrian Miron \\ Octavian Groza \\ Department of Geography, Faculty of Geography and Geology, Alexandru Ioan Cuza \\ University of Iasi, Iasi, Romania
}

\begin{abstract}
ASTRACT
This research seeks to investigate the nature and change of the roles of non-state armed groups in the Middle East, in particular, with a focus on Kurdish, Shiite and Islamic State groups. In order to understand the degree of transformation in the military geopolitical space in the Middle East, it is necessary to clarify and solve new empirical and analytical perspectives on the impact of important actors in the region, namely ISIS, YPG and Shia Militia. By analyzing them in depth, in detail and with multiple facets, we can offer new aspects regarding the changes of the outline of sovereignty, geopolitics and ideology, especially after the Arab uprisings after December 2010 (Arab Spring). In general, this analysis contributes to the study of geopolitics with a violent impact, of studies of a critical nature on security and of international relations, in particular through the pursuit and research of the ideologies and strategies of the new non-state armed actors. The bibliographic analysis and the mediated or direct contact with the different geopolitical realities of the contemporary world have led us to the idea that the (militarized) worldwide violence after the end of the cold war has undergone profound changes in its nature, intensity and spatial dynamics.
\end{abstract}

Keywords: non-state armed actors, military geopolitic, security, violence, spatial dynamics.

\section{INTRODUCTION}

The main idea of this analysis is that the (militarized) world-wide violence since the end of the Cold War has undergone profound changes in its nature, intensity and spatial dynamics. The number of armed conflicts in 2018 was slightly higher than in 2017 and much higher than ten years ago. The number of victims registered during this period was below average compared to the period after the Cold War. A key issue remains the internationalized conflicts - civil wars with foreign parties involved - in which, in 2018, the majority of the victims were registered.

The New Middle East is an enigma inside a puzzle. The emergence of non-state armed actors (ANSA - Armed Non-State Actor) was one of those guessing that can hardly be solved with the "key" of national and international interest. From suicide bombers to foreign fighters, the phenomenon has become an essential ingredient of the alarming and dangerous agenda in the Middle East and around the world. Even though ANSA presents direct challenges regarding the nature of the states and the strategic balance between the regional states, these are not a new phenomenon in international politics. The existence of such actors was a serious security issue in the Middle East long before the Arab Spring [1]. 
The Gulf was long penetrated by foreign powers, which they included in modern times, but were not limited to the Ottoman, Russian, British, US, and in a much more limited sense, Turkey, France and the Netherlands. The present era was largely defined first by the influence of the British Empire until 1971 and then by the US era, which is beginning to move in its later years [2].

The Gulf has remained a strategic hub for the last two hundred years. It first served as a gateway to the British Empire for the assurance and service of Imperial India. Since World War II, it has served as the focal point of the world's energy markets. The United States has played a vital role in ensuring not only the Arab states in the Gulf since Britain left the sub-region in 1971, but perhaps more importantly, the Strait, even in times of conflict, which has probably become the central nervous system of the Gulf. global energy markets [2],[3].

The Gulf is undergoing a series of profound changes at national, regional and international level. At a pivotal moment in its history, the moment when the balance of power between foreign powers moves from an order dominated by the US to one that witnesses the growing influence of China, Russia and India [2-4].

\section{METHODOLOGY}

The main method is the analysis of bibliographic and webography sources, especially of the websites specialized in the analysis of armed conflicts and organized violence. Based on the statistical information provided by these sources, we established a database that allowed statistical and cartographic analyzes and synthesis.

\section{Study area}

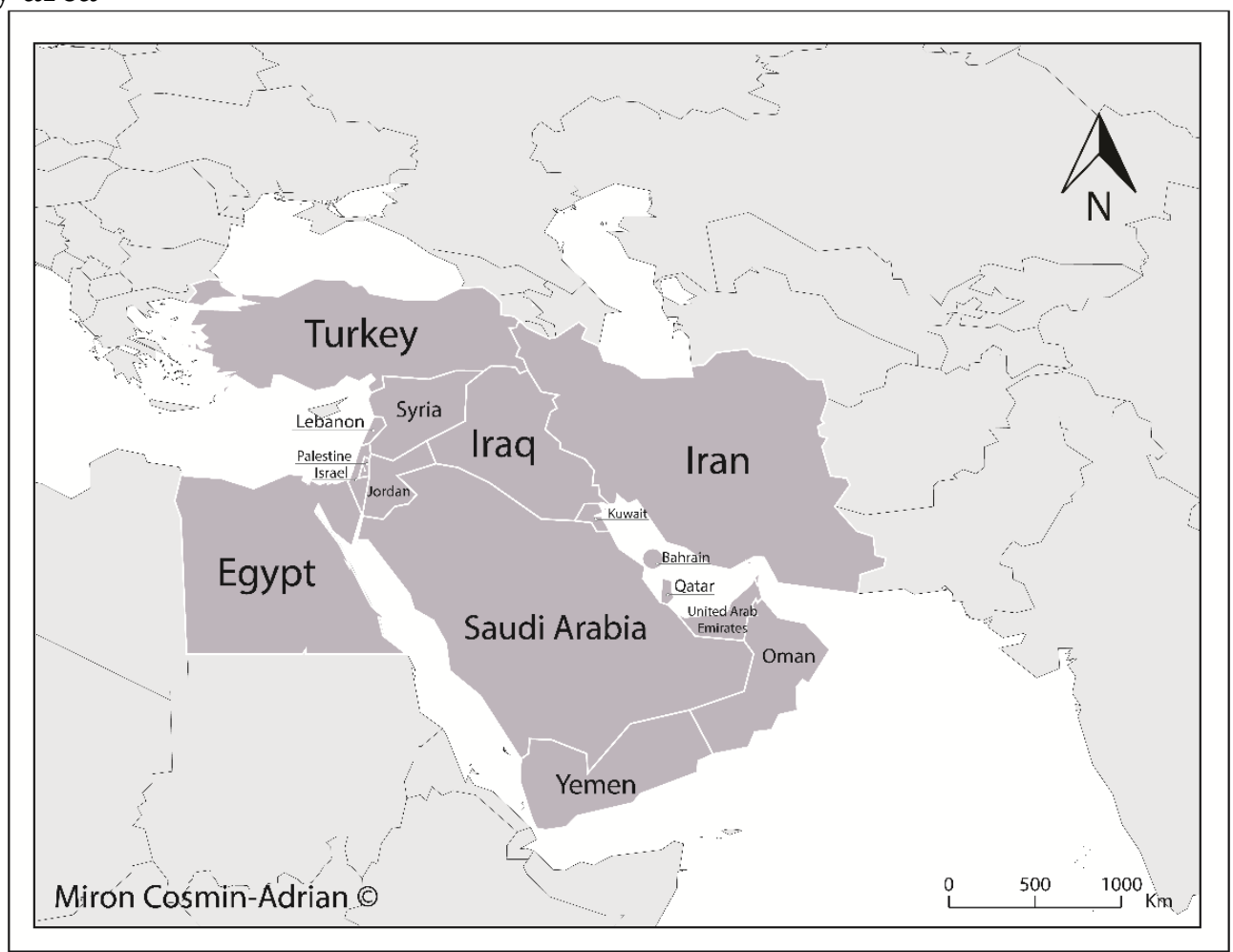

Figure 1. Research area - Location of the Middle East

The area of study that our research will focus on is the Middle East (Fig. 1), which is a transcontinental region that includes Western Asia (excluding the Caucasus), the whole 
territory of Turkey (including its European part) and Egypt (which is in the North Africa). The term has become broader as a replacement for the term Near East (Far East) since the early 20th century. The broader concept of the "Great Middle East" (or MENA) also adds the region to the Maghreb, Sudan, Djibouti, Somalia, Afghanistan, Pakistan and sometimes even Central and Trans-Caucasian Asia. The term "Middle East" has led to some confusion over its changing definitions over time. However, we will rank the 16 states we know belonging to this region.

\section{Statistical data used}

The main sources of information were: World Bank, SIPRI - Stockholm, ACLED (The Armed Conflict Location \& Event Data Project) and Uppsala University. The problems encountered in the realization of the database (still in work) was the lack of geocodes in the initial databases and the difficulty of understanding and ordering the metadata.

The database was created at the state level for the period 1989-2018 regarding the value of the defense budget, the flows at regional level of the arms trade, the number of nonstate conflicts, the actors involved, the interactions between them, the location of events (latitude $x$ longitude Fig. 2), the number of deaths - fatalities (Fig. 3), the type of events divided into 6 categories - for the last four years 2014 - 2018 (battle, explosions / remote violence, protests, riots, strategic developments, violence against civilians).

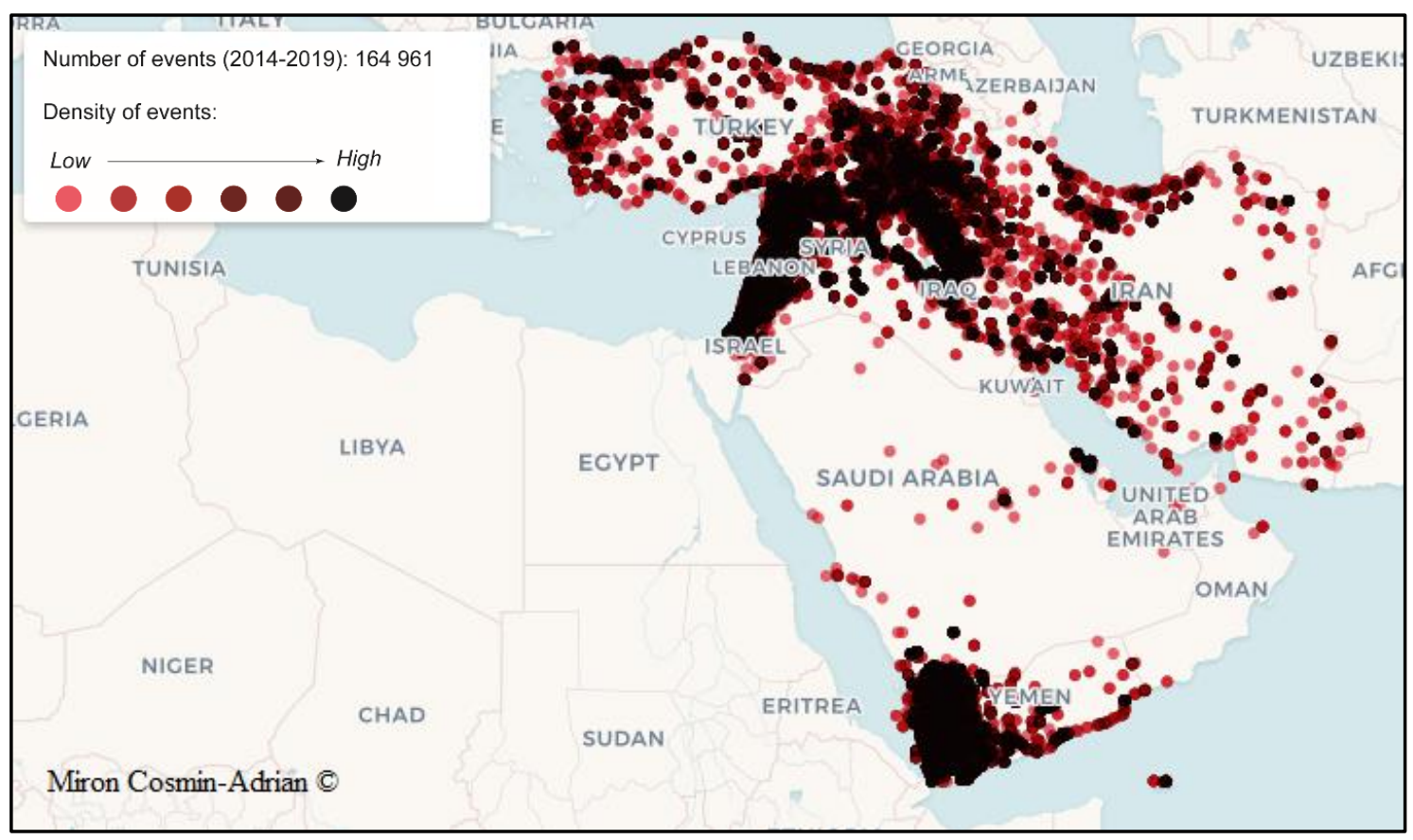

Figure 2. The spatial distribution of events between 2014-2019 and their density. Source date: ACLED 2018

Through statistical and cartographic analyzes of the databases based on studies conducted by independent institutions, our research performs a classification of the types of armed / militarized violence registered in the world space and their dynamics after the disappearance of the ideological blocks. The replacement of ideological interests with economic or political interests, as major causes of the initiation and unfolding of military (militarized) conflicts, has changed both their nature and intensity, but especially their geographical manifestation. From the direct / indirect military / militarized conflicts 
between the ideological blocks or between the national states, there has been a gradual transition to infra-national, intra / inter-regional, inter-ethnic, intra / inter-confessional, even inter-civilizational conflicts, if they were to we believe the thesis launched in 1993 by Samuel S. Huntington. Military confrontations of systemic and symmetrical type have made more and more room for the a-symmetrical and non-systemic ones, usually of the dyadic type, which mobilize, together with governments, different groups, factions or organizations more or less clandestine.

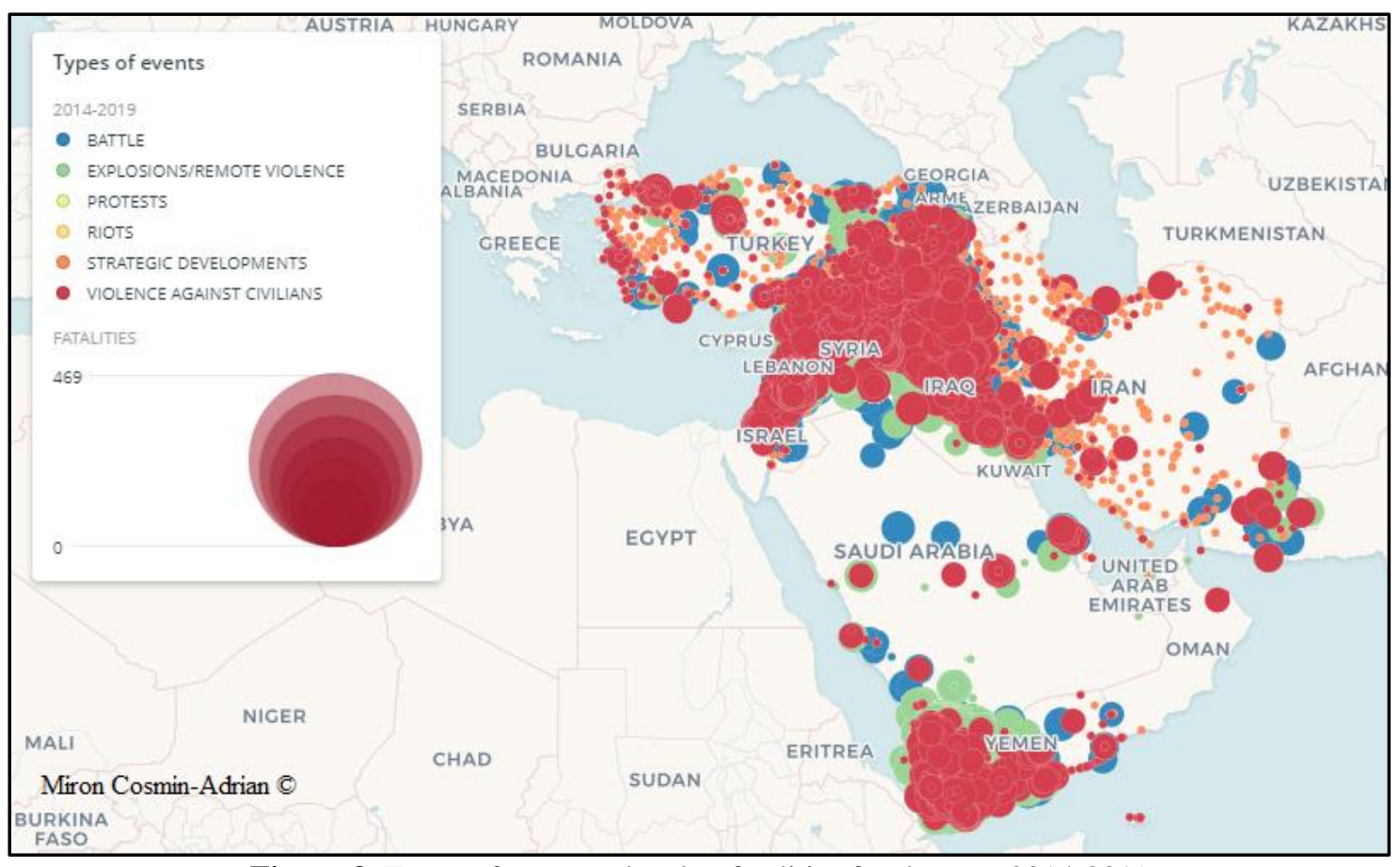

Figure 3. Types of events related to fatalities for the year 2014-2019

Source date: ACLED 2018

\section{RESULTS AND DISCUSSIONS}

Since 2008, the peace level of the countries of the world has deteriorated. In this period there were only two years when world peace improved. The decline of the peace index for this decade was caused by a wide range of factors, including the increase of terrorist activity and the intensification of conflicts in the Middle East. The Middle East and North Africa region remains the least peaceful in the world. However, despite the ongoing armed conflict and instability in the region, it has become a little quieter over the last year. Most of the improvement has taken place in the field of security, especially in terms of the impact of terrorism and the number of refugees fleeing conflict [5],[6].

The combined military expenditures of the countries (according to SIPRI data) in the Middle East region for which the data are available in 2017 increased continuously between 2009 and 2015, resulting in a total increase of about $41 \%$. However, with the decline in oil prices, military spending in these countries decreased by $16 \%$ between 2015 and 2016. Their spending increased again in 2017 , by $6.2 \%$, but their total was still $11 \%$ higher. small than in 2015 [7].

From the point of view of the percentage of GDP allocated for defense, several areas of importance can be distinguished, among which the Middle East is one of those (Fig. 4). Middle Eastern states are willing to allocate a considerable share of gross domestic product to the military budget. This clearly shows how the states in this region see their 
military position. For Saudi Arabia, this percentage points to the focus on its main competitor, Iran. In addition to this, the war in Syria and Yemen forces the countries around them, in addition to increasing military spending, the acquisition of new weapons to achieve their goals.

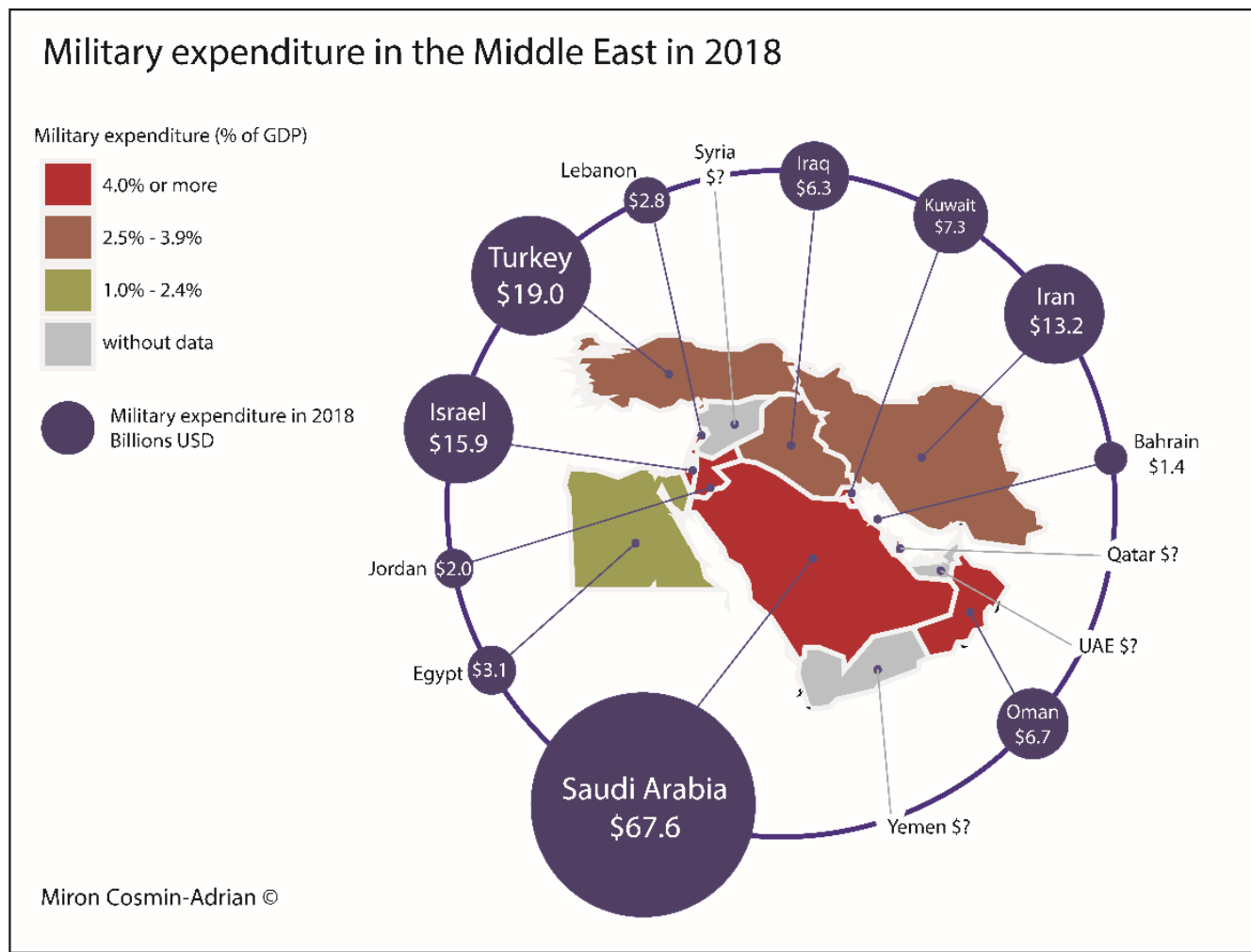

Figure 4. Military expediture in the Middle East in 2018. Source date: SIPRI 2018

Arms imports by states in the Middle East in 2018
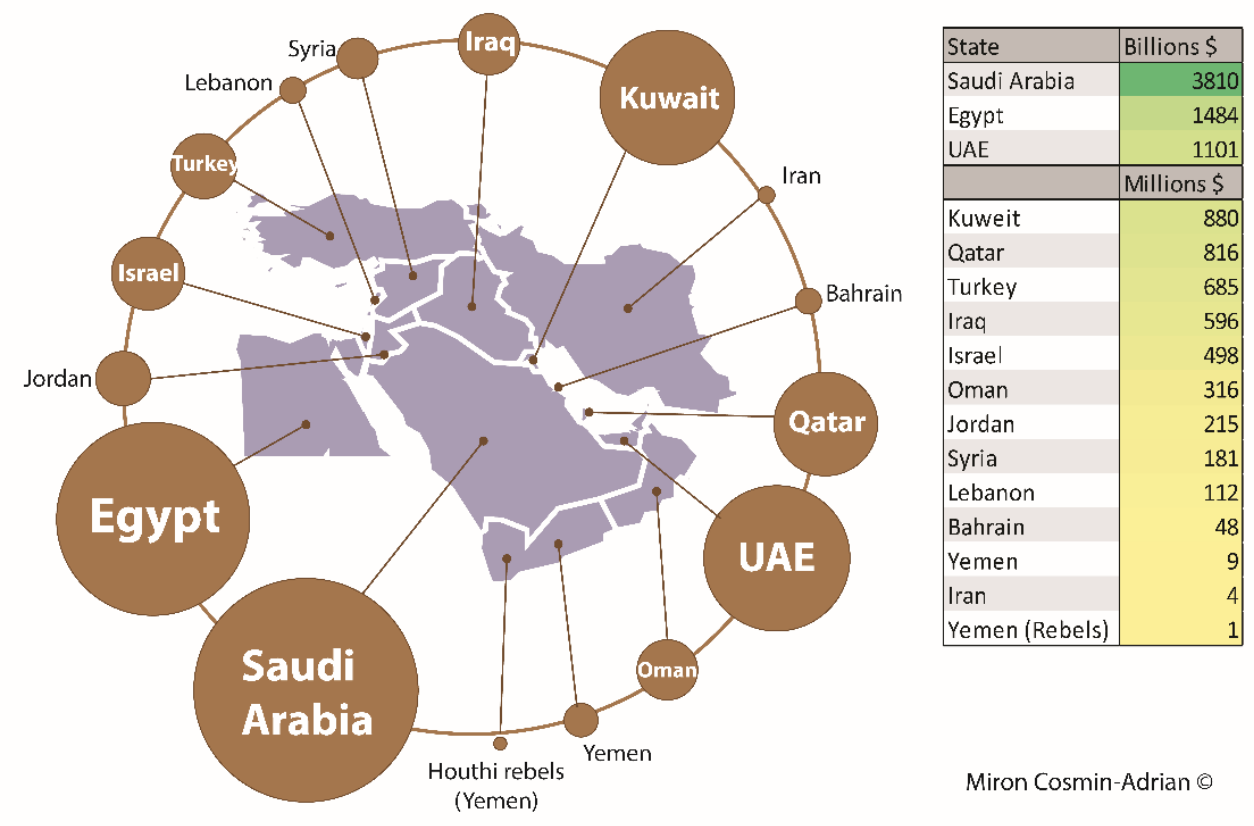

Figure 5. Arms imports by states in the Middle East in 2018. Source date: SIPRI 2018 
Imports of weapons by the Middle East countries (Fig.5) increased by $87 \%$ between 20092013 and 2014-2018. Four of the top ten weapons importing countries in 2014-2018 were in the Middle East: Saudi Arabia, which received 33\% of arms transfers to the region, Egypt $(15 \%)$, the United Arab Emirates $(11 \%)$ and Iraq $(11 \%)$. The United States provided 54\% of total arms transfers to the region, Russia 9.6\% and France 8.6\% [7]. Imports of weapons by some Arab Gulf states increased sharply between 2009-2013 and 2014-2018. Among the key reasons for these increases were mutual distrust between Iran, on the one hand, Saudi Arabia and the UAE, on the other; the war in Yemen, which began in 2015; and since mid-2017 hostile relations between Qatar, on the one hand, and Saudi Arabia and the UAE, on the other.

Competition for regional hegemony is a fact of life in the international system and is very well defined in this region of the world - whether there are long-standing rivalries such as those between Iran and Iraq [8] or more current rivalries such as Iran and Kingdom of Saudi Arabia [9]. An important part of this hegemonic competition is represented by the states that sponsor violent groups as part of a tender to revise or maintain the status quo [10]. As a result of the civil wars and / or the use of military force by foreign powers, four countries in the region (Yemen, Iraq, Syria and Libya) are represented as failed states, which are able to provide sanctuary for many of the most violent and violent resistance of non-state actors (VNSA), along with the wide assortment of criminal gangs and war profiteers. What has appeared in a more virulent form in the region since 2001 [11], however, is the entry of the disruptive force of the transnational VNSA whose radical Islamic political and social vision for the region requires the violent transformation of the Islamic world from the house of Islam, of the country and peoples of the Middle East.

Several states in the Middle East region do not have a monopoly on the use of force within their borders and this means that, at the moment, the VNSA has a vital and decisive power during the political events in the region. The degree or level and current nature of conflicts in the region seem to further degrade the power that the state has. This allows not only the large VNSA to influence the politics of the region, but also the multitude of hundreds of other groups that also act as critical factors in the course and speed of political change. To paraphrase Hobbes, life in the Middle East seems to be even shorter, even more brutal and seemingly hopeless.

There are a wide range of groups operating in the shadow of larger Islamic mass movements and serving as strategic paramilitary partners for more established VNSAs, such as Hamas or Hezbollah. The nature of their affiliation is generally intended to be dark in order to grant a certain level of political immunity to different persons of significant character. Groups such as the Palestinian Islamic Jihad (PIJ) [12],[13] and the Al Aqsa Martyrs' Brigade (AAMB) [12],[13] have persisted for decades, but they remain clandestine and maintain very limited and exclusive membership. In addition to the violent actions taken by groups at an isolated level, they often also serve as strategic partners for other larger groups that are designed as mass movements. There are also several groups that act as local agents of foreign governments, such as Iran or transnational actors, such as Al Qaeda.

Islam inspires the political views of all four organizations that I will try to focus on in this research. But, as usual, every organization / institute translates different Islam into political and violent actions. All four groups (or their partners) were taken and detained at one point of violence. All are capable of competing with both rival VNSAs on the battlefield or with Western-style military forces in conventional combat. The four groups are: 
1. Hamas - a Sunni Islamist Palestinian group formed in 1987 , which is dedicated to forming an independent Palestinian homeland.

2. Hezbollah - A Lebanese Shiite Islamic group formed in 1982, dedicated to the political rights of the Shiite community in Lebanon and to discouraging Israel.

3. Al Qaeda and its affiliates (AQ) - a transnational Sunni Salafi Jihadi group whose core was formed in 1988 after the Soviet-Afghan war, focused on restoring the caliphate, but more on the defensive jihad to defeat the "enemy". Far from it, they claim to have been the main cause of the oppression of Islamic believers - that is, Western powers, such as the US, who support Middle Eastern leaders, whom they consider to be apostates.

4. Islamic State of Iraq and Syria (ISIS) and its partners - A Sunni Salafi-Jihadi group formed as a spin off of Al Qaeda in 2014. They focused on establishing the Caliphate in the very near term and prosecuting of global offensive jihad to expand the geographical area of the Caliphate.

\section{CONCLUSION}

VNSA plays a decisive role in Middle East policy. Our research has focused on a number of established organizations over time, which have succeeded in creating campaigns supported by strategic anti-government violence to achieve their political goals and visions, through various means such as terror use, guerrilla warfare, conventional punishment and war to provoke governments to certain territories. Syrian nationalist groups trying to overthrow the Assad regime and Islamic nationalist groups such as Hamas and Hezbollah are focused on state-building projects within the internationally recognized boundaries of their particular states. However, the transnational Salafi-Jihadi movements and their networks of expanding partners are pursuing a truly global jihad and throwing the state's best-known boundaries into irrelevance. They are trying to separate the Middle East and the international order, as we know it, to model it according to their interpretation of the ideology of the founders of Islam. The civil wars in Yemen and Libya have continued unabated since 2011, leading to an even deeper failure, allowing a variety of VNSAs to flourish and govern fragments of these countries.

VNSAs are formidable challengers of the legitimacy and security of the existing state system in the Middle East and of those who govern these states.

\section{REFERENCES}

[1]Yeșiltaș M., Kardaș T., Non-state armed actors in the Middle East - geopolitics, ideology, and strategy, Switzerland, Springer International Publishing, pp 3-7, 2018.

[2]Bazoobandi S., The New Regional Order in the Middle East - Changes and Challenges, Washington, DC, USA, Springer International Publishing, pp 93-95, 2019.

[3] McMillan M., E., From the First World War to the Arab Spring - What's really going on in the Middle East?, London UK, Palgrave Macmillan, pp 213-235, 2016.

[4] Nothacker M., A new regional order in the middle east?, Hamburg, Körber Foundation, 2014 (May).

[5] IEP - Global terrorism index 2018 - The Institute for Economics and Peace, 2017.

[6] IEP - Global peace index 2018 - The Institute for Economics and Peace, 2018.

[7] SIPRI - SIPRI Yearbook 2018 - Stockholm, Oxford University Press, 2018.

[8] Murray W., Woods K., W.,The Iran-Iraq War: A Military and Strategic History, Cambridge, Cambridge University Press, 2014. 
[9] Gause III F., G., Beyond Sectarianism - The New Middle East Cold War, Analysis Paper Brookings Doha Center, 2014.

[10] Byman D.,Deadly Connections - States That Sponsor Terrorism, Cambridge: Cambridge University Press, Foreign Affairs, Vol. 84, No. 6 (Nov. - Dec., 2005), pp. 135-136 2005.

[11] Fawaz G., The Far Enemy: Why Jihad Went Global, Cambridge, Cambridge University Press, Journal of Middle East Studies, 39(2), pp. 326-328, 2005.

[13] Holly F., Palestinian Islamic Jihad, Council on Foreign Relations, 2008 (April).

[14] Holly F., Al-Aqsa Martyrs Brigade, Council on Foreign Relations, 2005 (November). 